\title{
Cherubism: Clinicoradiographic Features and Treatment
}

\author{
Gabriela de Morais Gouvêa Lima ${ }^{1}$, Janete Dias Almeida ${ }^{2}$, Luiz Antonio Guimarães Cabral ${ }^{2}$ \\ 'Postgraduation Program in Oral Biopathology, São José dos Campos Dental School, São Paulo State University - UNESP, \\ São José dos Campos, São Paulo, Brazil \\ ${ }^{2}$ Department of Biosciences and Oral Diagnosis, São José dos Campos Dental School, São Paulo State University - UNESP, \\ São José dos Campos, São Paulo, Brazil
}

\section{Corresponding Author:}

Gabriela de Morais Gouvêa Lima

Rua Engenheiro João Fonseca dos Santos, 158, apto. 13 B , Vl. Adyanna

CEP 12243-690, São José dos Campos, São Paulo,

Brazil

Phone: (12) 33075231

E-mail: gabrielademorais@yahoo.com.br

\begin{abstract}
Objectives: Cherubism is a congenital childhood disease of autosomal dominant inheritance. This disease is characterized by painless bilateral enlargement of the jaws, in which bone is replaced with fibrous tissue. The condition has sui generis clinical, radiographic and histological features, of which the clinician should be aware for a better differential diagnosis in the presence of a fibro-osseous lesion affecting the bones of the maxillomandibular complex. The purpose of present paper was to review the literature and to report the most important aspects of cherubism in order to facilitate the study of this disease.

Material and Methods: Literature was reviewed about cherubism, emphasizing the relevant clinicoradiographic features and treatment. Literature was selected through a search of PubMed and Scielo electronic databases. The keywords used for search were adolescent, cherubism, cherubism/physiopathology, cherubism/treatment, cherubism/radiography. A manual search of the reference lists of the identified articles and the authors' article files and recent reviews was conducted to identify additional publications. Those studies that described new features about cherubism were included in this review.

Results: In total 44 literature sources were obtained and reviewed. Studies that described new features about cherubism physiopathology, diagnostics and treatment were reviewed.

Conclusions: Despite the exceptions, cherubism is a clinically well-characterized disease. In cases of a suspicion of cherubism, radiographic examination is essential since the clinical presentation, the location and distribution of the lesions may define the diagnosis. Histopathological examination is complementary. Nowadays, genetic tests should be used for final diagnosis of cherubism.
\end{abstract}

Keywords: adolescent; jaw diseases; cherubism.

Accepted for publication: 15 March 2010

To cite this article:

Lima G de M, Almeida JD, Cabral LA. Cherubism: Clinicoradiographic Features and Treatment.

J Oral Maxillofac Res 2010 (Apr-Jun);1(2):e2

URL: http://www.ejomr.org/JOMR/archives/2010/2/e2/e2ht.pdf

doi:10.5037/jomr.2010.1202 


\section{INTRODUCTION}

Cherubism is a rare disease of autosomal dominant inheritance characterized by painless, frequently symmetrical, enlargement of the jaws as a result of the replacement of bone with fibrous tissue $[1-16, \underline{20}, \underline{29}]$. The disease is also called familial fibrous dysplasia of the jaws, but recent genetic investigation has shown it to be a separate entity at the molecular level [7]. Furthermore Lannon et al. [30] mentioned necessity to distinguish cherubism from central giant cell granuloma and giant cell tumour of the jaws, with which it holds a false synonymity.

A molecular pathogenesis of cherubism has been proposed, with the detection of a mutation in the gene encoding SH3 - binding protein 2 (SH3BP2) $[\underline{6}, \underline{10}, \underline{31}]$ and possible degradation of the Msx-1 gene which is involved in the regulation of mesenchymal interaction during craniofacial morphogenesis [11]. It is believed that the different clinical manifestations of cherubism are due to the changes secondary to mutations or incomplete penetrance [10].

Cherubism is usually diagnosed in children aged 2 to 7 years, with the observation of exacerbation of its manifestations within the first 2 years after diagnosis $[5,32]$ and of stabilization or even regression after puberty $[1-14,20]$. Boys are more affected than girls at the proportion of $2: 1[\underline{3-6}, \underline{14}, \underline{33}]$.

Clinically, cherubism is characterized by bilateral enlargement of the mandible and/or maxilla, causing a rounded face and swollen cheeks accompanied by upward-looking eyes. This condition gives the patient the appearance of cherubs depicted in baroque artwork $[\underline{1}, \underline{4-12}, \underline{14}, \underline{16}, \underline{20}, \underline{34}]$; hence, the name of the disease introduced by Jones [17], who published the first four cases affecting the same family.

The purpose of the present paper was to review the literature and to report the most important aspects of cherubism in order to facilitate the study of this disease.

\section{MATERIAL AND METHODS}

Literature was reviewed about cherubism, emphasizing the relevant clinicoradiographic features, physiopathology and treatment. Literature was selected through a search of PubMed and Scielo electronic databases. The keywords used for search were adolescent, cherubism, cherubism/physiopathology, cherubism/treatment, cherubism/radiography. A manual search of the reference lists of the identified articles and the authors' article files and recent reviews was conducted to identify additional publications. Those studies that described new features about cherubism physiopathology, diagnostics and treatment were included in this review.

\section{RESULTS}

\section{Pathogenesis}

Although rare, cherubism is part of the differential diagnosis of bone diseases affecting the maxillomandibular complex and the professionals should therefore have knowledge of the disease. The most accepted theory regarding the pathogenesis of cherubism is its association with an autosomal dominant gene, i.e., family inheritance $[1-9,11-$ $17,23,35]$. However, there are reports of the cases in which no criteria of heredity could be established [1$\underline{3}, \underline{9}, \underline{11}, \underline{12}, \underline{15}, \underline{16}, \underline{24}]$, or in which an autosomal recessive pattern of inheritance was suggested [5]. In addition to genetic factors, Caballero and Vinals [14] indicated other possible causes of cherubism such as mesenchymal alterations during jaw development, an odontogenic origin or even hormonal and traumatic factors. Today we know that a mutation in the gene encoding SH3BP2 plays a role in the disease $[\underline{6}, \underline{7}, \underline{10}, \underline{11}, \underline{21}]$. There are indications that the gene SH3BP2 plays a role in regulating the increased osteoblast and osteoclast activities that are seen in normal tooth eruption, and point mutations in the gene could cause pathologic activation of osteoclasts $[\underline{21}, \underline{31}, \underline{36}]$. Silva et al. [11] reported the degradation of Msx-1 gene, which is involved in the regulation of mesenchymal interaction during craniofacial morphogenesis. In contrast, Sarda et al. [10] detected a point mutation at the SH3 binding site of the SH3BP2 gene, and $\mathrm{Li}$ and $\mathrm{Yu}[\underline{6}$ ] observed mutations in exon 9 of the same gene.

According to Hyckel et al. [26] cherubism is a locationstable phenomenon found only in the jaws with multiple occurrences. Furthermore, structure-associated process is a very likely link to the pathogenic mechanism. The authors defined cherubism as a genetically determined alteration of tooth germ development. They proposed the molecular model of cherubism pathogenesis which is based on interaction between a disturbed (due to mutation in SH3BP2) parathyreoid hormone related protein (PTHrP) receptor with the Hox gene Msx1 activity. Thus the temporal and spatial termination of the clinical symptoms is explained by SH3BP2 dependent signal transduction pathways interfering with jaw morphogenesis. The cap stage of the second and third molars, a spatial compartmentation does not take place, being necessary for normal dental development. This leads to the dysregulation of mesenchymal 
bone formation, and to the development of giant cell granulomas containing osteoclasts.

\section{Clinical characteristics and symptoms}

Patients with cherubism, generally males at a proportion of $2: 1[\underline{2}, \underline{3}, \underline{5}, \underline{7}, \underline{14}]$, present the same clinical characteristics: enlarged face due to swelling of the jaws which is bilateral in most cases, bone consistency of the lesion, intact mucosa, dental malocclusion, upward-looking eyes in the case of maxillary involvement, and absence of pain $[\underline{2}, \underline{4-9}, \underline{11}, \underline{12}, \underline{14-}$ 17,37]. The concomitant presence of cervical and/or submandibular lymphadenopathy has been reported $[\underline{8}, 13,14,16,23]$. The first signs of manifestation of the disease are generally observed at about 2 years of age, followed by accelerated growth from 8 to 9 years and spontaneous interruption after puberty [1$\underline{3}, \underline{5}, \underline{9}, \underline{11}, \underline{12}, \underline{14-16}, \underline{24}, \underline{29}, \underline{38}]$. However, Ashraf [1] and Kalantar [4] suggested that, as observed from 3 to 7 years of age, growth might be more active after puberty. In addition, the age at recognition of symptoms varies according to the severity of the disease and degree of deformity. In such cases where the onset of symptoms of cherubism occurs after puberty, the time of remission of the process is expected to be prolonged $[\underline{1}, \underline{3}, \underline{4}]$.

In cases where the clinical symptoms are typical to cherubism, the final diagnosis should be based on radiographic findings and histology, because the clinical picture of cherubism at initial examination are similar to other lesions that cause mandible enlargement, such as autosomal dominant osteosclerosis [22].

\section{Dental alterations}

Dental alterations associated with cherubism include early exfoliation of deciduous teeth, impaction and/ or displacement of teeth $[\underline{1}, \underline{4-14}, \underline{16}, \underline{20}]$, which radiographically seem to float in radiolucent areas, conferring the so-called "floating tooth appearance" $[\underline{14}, \underline{20}]$. In addition, ectopic tooth eruption, agenesis of permanent teeth, mainly of the second and third molars [26], due to involution of their germs [14], and root resorption of existing teeth are observed $[4,5]$. These alterations result in malocclusion as well as in problems of phonation and swallowing, the latter being exacerbated by flattening or inversion of the palatal cleft $[\underline{1}, \underline{4-6}, \underline{8-12}, \underline{14}, \underline{16}]$.

\section{Biochemical parameters}

With regard to biochemical parameters, serum calcium and phosphorus concentrations and TSH, FSH, LH, T4 and T3 hormone levels are usually within normal limits, but alkaline phosphatase levels might be elevated $[\underline{1}, \underline{5}, \underline{8}, \underline{10}, \underline{11}, \underline{13-15}]$. A constant finding in these patients is the enlargement of submandibular and cervical lymph nodes $[\underline{5}, \underline{8}, \underline{13}, \underline{14}]$.

\section{Radiography}

Radiographically, cherubism is characterized by expansive radiolucent, generally multiloculated lesions clearly delimited by cortical bone and distributed bilaterally in the posterior quadrants of the mandible and/or maxilla $[\underline{6}, \underline{8}, \underline{9}, \underline{12}, \underline{20}]$. Bone alterations generally starts in the region of the angle and ascending ramus of the mandible, continue to the mandibular body, displacing the mandibular canal, and in some cases extending to the coronoid process $[1-3, \underline{8}, 14,17,23]$. Involvement of the condyle is rare $[\underline{3}, 4, \underline{9}, \underline{11}]$. In the maxilla, the injury process starts in the maxillary tuberosity region $[\underline{4}, \underline{5}, \underline{9}, \underline{10}, \underline{14}]$. When process is starting in mandible, maxillary lesions manifest at a later time [14]. In more severe cases, infiltration of the orbital cavities may cause exacerbated exophthalmia and limiting ocular movements $[\underline{1}, \underline{11}, \underline{15}, \underline{16}, \underline{39}]$.

The lesions of cherubism can be classified according to their extent: grade I, bilateral involvement of the ascending ramus of mandible; grade II, bilateral involvement of the ascending ramus of mandible and maxillary tuberosity; grade III, complete involvement of the maxilla and mandible compromising the coronoid processes and condyles $[\underline{1}, \underline{4}, \underline{16}]$.

Radiographically identified multilocular radiolucent lesions mainly are affecting the body and ascending ramus of the mandible. The coronoid process might be involved $[23,24]$ and the condition extends to the maxilla, preferentially to the region of maxillary tuberosity $[\underline{20}, \underline{23}]$. The radiolucencies are mainly bilateral and may affect the lower portion and fundus of the orbit which cortical bone appears to be thin but intact. The teeth are found to be displaced and impacted and root resorption is observed; the mandibular canal is often displaced $[\underline{1-3}, \underline{5}, \underline{8}, \underline{11}, \underline{12}, \underline{14-16}, \underline{23}]$. The facial sinuses frequently appear to be obliterated, resuming their pneumatic function after regression of disease activity $[\underline{5}, 14]$. Some authors have reported involvement of the condyles $[\underline{1}, \underline{3}, \underline{4}]$.

\section{Diagnostics}

Observed radiographic appearance might be confused with other lesions containing giant cells: hyperparathyroidism $[\underline{5}, \underline{8}, \underline{9}, \underline{18}]$, and/or osteomalacia [19]. Regarding the differential diagnosis, it should be emphasized that, whereas central giant cell lesions affect the central portion of the mandibular body and giant cell 
tumours rarely involve bone of the maxillomandibular complex, in cherubism the lesions are generally bilateral and involve both the maxilla and the mandible $[\underline{3}, 18]$. The radiographic techniques used for the diagnosis of suspected cases of cherubism include posteroanterior radiography of the jaws $[\underline{5}, 16]$, orthopantomography $[1-4,6-9,11,12,14]$ and teleradiography $[\underline{3}, 14,16]$. Computed tomography is a useful tool for the assessment of the damage caused by the process either during the analysis of disease progression or during surgical planning $[\underline{3}, \underline{5}, \underline{7-9}, \underline{40}]$. Advancements in virtual three-dimensional reconstruction of anatomic structures based on computed tomography or cone beam computed tomography data can provide for more predictable individual treatment planning [41]. According to Mnari et al. [42] magnetic resonance imaging is useful for identifying orbital involvement.

Similarity with central giant cell lesions and hyperparathyroidism is also present in the histological findings. As observed in these conditions, in cherubism multinucleated giant cells are found scattered throughout collagenous and vascularized fibrous connective tissue with the observation of dense connective tissue which might be highly or poorly cellularized and contain a smaller or larger number of collagen fibbers, respectively, depending on the progression of the lesion $[\underline{1}, \underline{3-8}, \underline{11}, \underline{14}]$. This connective tissue is richly vascularised and mainly located around giant cells, with the possible presence of bone spicules and hemosiderin deposits $[1,3-5,7, \underline{8}, 11-16,18]$. It is believed that these giant cells have osteoclast activity $[5,13]$. Southgate et al. [13] found that multinucleated cells in cherubic lesions had phenotypic characteristics of osteoclasts, resorbing bone in vitro. The specific histological finding of cherubism is the presence of eosinophilic perivascular cuffing which, however, is not always present $[\underline{3}, \underline{14}, \underline{24}]$ and histology is of limited diagnostic significance [26]. Figures 1 to 4 shows the extraoral clinical and radiographic features of two boys ( 7 and 9 years old) with cherubism involving the angle and ascending ramus of the mandible. The cases were retrieved from the archives of the Discipline of Stomatology, São José dos Campos Dental School, UNESP. Figures 5 and 6 refer to the follow-up of the case shown in Figures 3 and 4 at nine years after diagnosis.

Laboratory tests contribute to the characterization of disease since hematological parameters such as calcium and phosphorus are normal and only alkaline phosphatase levels might be elevated [1$\underline{3}, \underline{5}, \underline{6}, \underline{8}, \underline{11}, \underline{13}, \underline{15}, \underline{23}]$. According to George et al. [ㅍ], the increase in alkaline phosphatase can be explained by the phase of development in most individuals affected by the disease. In contrast, in hyperparathyroidism serum calcium and PTH levels are increased and phosphorus levels are found to be normal or reduced $[15,19]$.

Cytogenetic and molecular studies have being used on cherubism diagnostic, such as fluorescence in situ hybridization and quantitative analysis of Msx-1 expression in different tissues [26].

\section{Treatment}

Once the diagnosis is established, therapeutic management should be evaluated. Treatment options include waiting for stabilization and spontaneous remission of the disease, tooth extraction in areas showing fibrous alterations, cosmetic osteoplasty of the affected jaws after regression of disease activity or, in the case of functional impairment, curettage of the lesions and treatment with calcitonin $[\underline{32}, \underline{34}, \underline{43}, 44]$. The policy of waiting for disease regression, followed by the evaluation of physiological bone remodelling, is the most recommended $[\underline{3}, \underline{5-8}, 11,12,14-16,23,26]$. However, it is still uncertain whether this approach is the most effective one since only a few cases of longterm follow-up have been reported and in most cases submitted to curettage or jaw osteoplasty surgery was indicated early $[1,3-5,17]$. Curettage has been suggested to be as a good approach since this intervention stimulates bone replacement []ㅡ. However, in his original study Jones [17] treated two boys by bilateral curettage and one girl was submitted to curettage on one side and multiple tooth extractions on the other side, with no difference in outcome being observed between the two sides. According to the author, this finding might indicate that cherubism is associated with odontogenesis and multiple extractions would resolve the case. There is general agreement that in extreme cases in which important functions are impaired, surgical intervention should be performed as early as possible $[4,5, \underline{8}, 11, \underline{14}, \underline{19}]$. Radiation therapy has been abandoned as a treatment of cherubism because of the potential risk of osteoradionecrosis or even malignant transformation of the process resulting in osteosarcoma $[\underline{2}, \underline{5}, \underline{8}, \underline{10}, \underline{27}]$. When possible, follow-up is always a valuable choice [26].

According to Novack and Faccio [27], hypotesis that cherubism is caused by enhanced cytokine tumour necrosis factor $\alpha$ (TNF- $\alpha$ ) production by myeloid cells due to an activating mutation in Sh3bp2 not only represents a major advancement in the understanding of the disease but suggests new potential options for its treatment. Although cherubism was described more than 70 years ago, the rather sparse literature in this area has provided little insight on disease effective therapies. As a major pathogenic factor of the identification of TNF- $\alpha$ for the patients with this rare disease, is significant news. Anti-TNF therapies are already in clinical practice for 


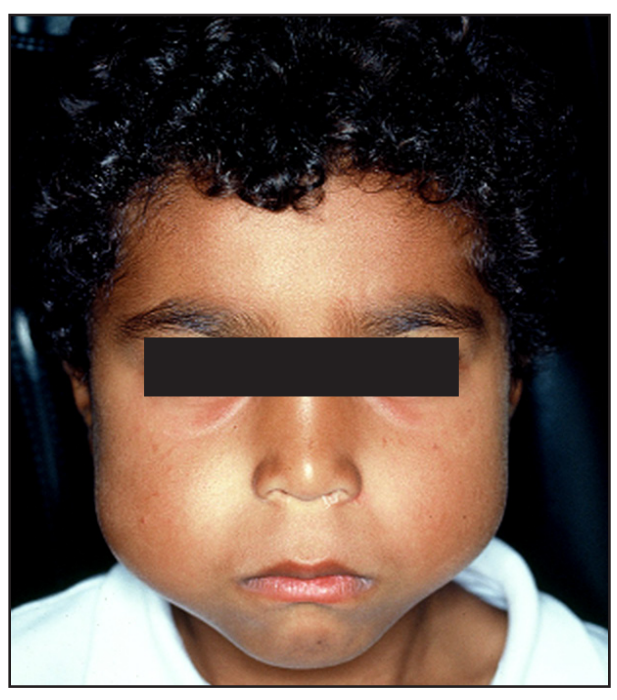

Figure 1. Photograph of a 7 year old boy with cherubism showing bilateral swelling at the mandibular angles.

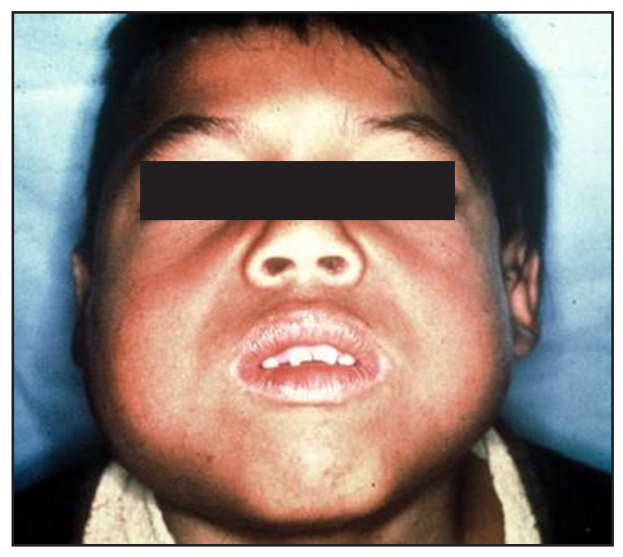

Figure 3. Photograph of a 9 year old boy with cherubism showing bilateral swelling of the angle and ascending ramus of the mandible, stretching the skin in the nasogenial region.

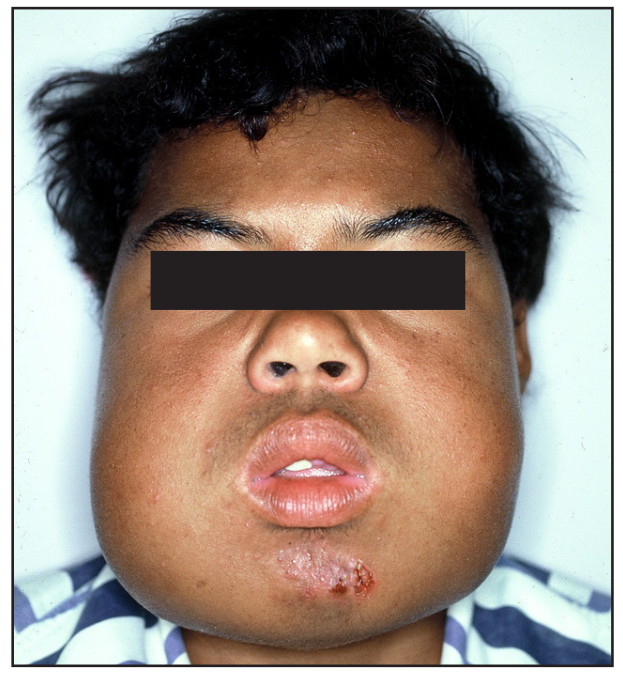

Figure 5. Photograph of the same patient as in Figure 3 after 9 years of follow-up, demonstrating expressive progression of the disease.

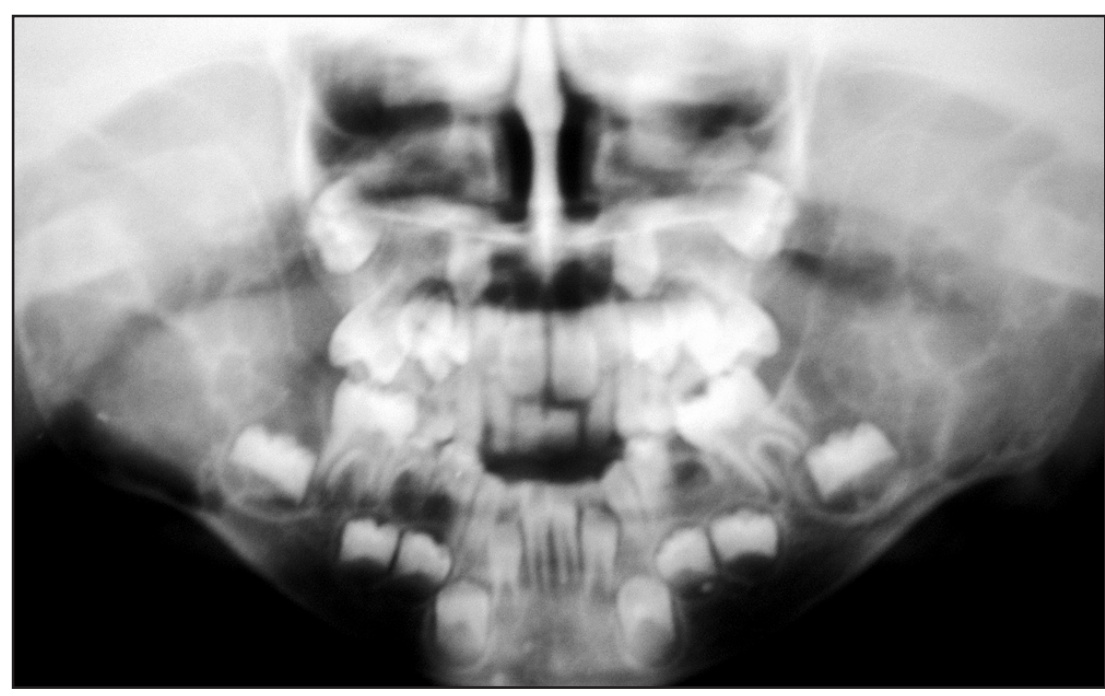

Figure 2. Orthopantomograph of the same patient as in Figure 1. Note the bilateral swelling caused by expansion related to multilocular bone lesions of the angle and ascending ramus of the mandible and coronoid process.

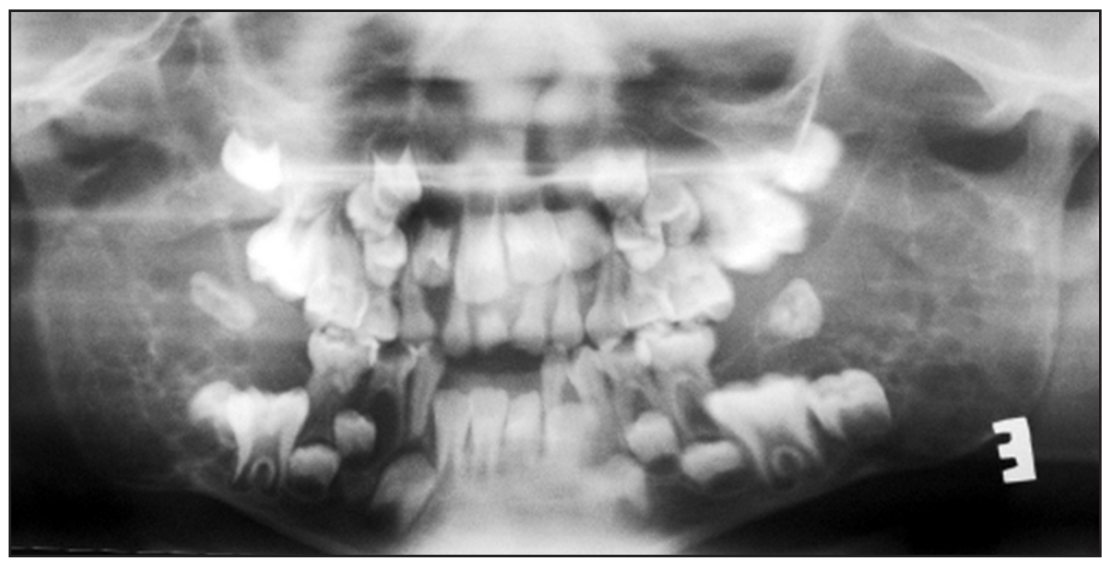

Figure 4. Orthopantomograph of the same patient as in Figure 3. The image reveals bilateral swelling of the angle, ascending ramus of the mandible and coronoid process caused by multilocular bone lesions. Note the lack of involvement of the condyles.

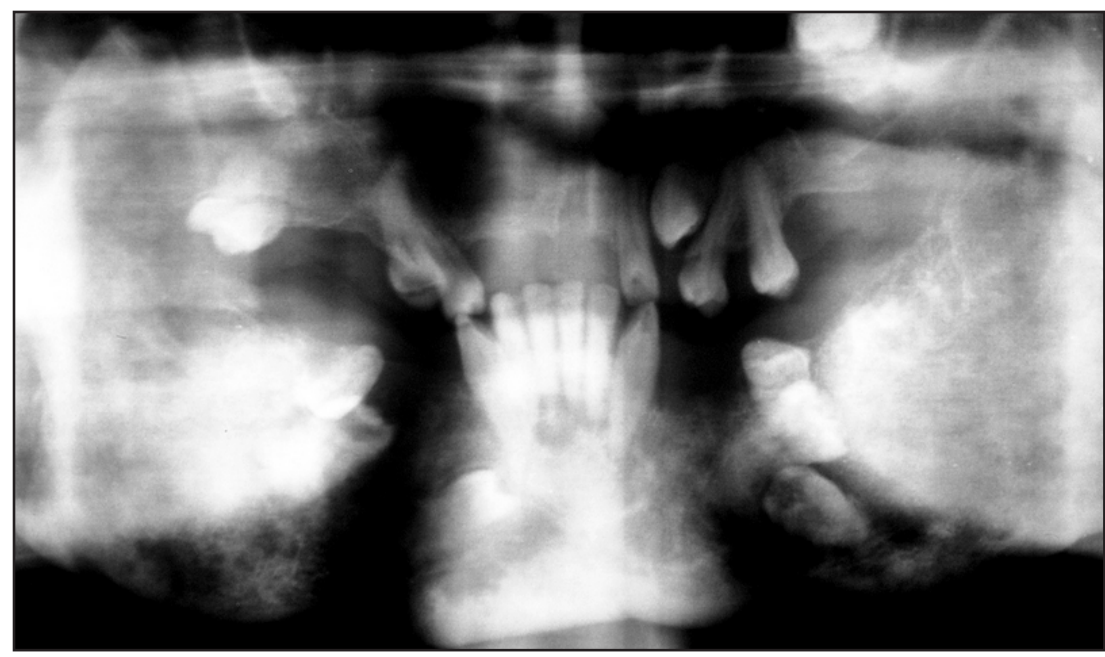

Figure 6. Orthopantomograph of the same patient as in Figure 5, revealing radiographic alterations characterized by greater radiopacity resulting from bone deposition and confirming the lack of involvement of the condylar regions. Note the malpositioning and retention of teeth. 
the treatment of rheumatoid arthritis. If these drugs will prove the effectiveness in the treatment of cherubism it can be hoped that the interval from laboratory discovery to clinical use would be short [27].

A study by von Wowern [25] followed-up 18 patients over the long term and found a significant relationship between the grade of cherubism and maximal buccal bone expansion, as well as the age for normalization, and the grade of cherubism and number of missing teeth. Neither patient showed any radiolucencies or radiographic signs of sclerotic areas or sclerotic thickening of the mandibular ramus. In the same study, no larger surgical corrections with removal of the main part of the lesional tissue were performed in any of the patients.

A prosthetic treatment for a cherubism patient was reported by Yilmaz at al. [28]. The patient's physical appearance showed characteristic cherubic features. The maxillary canines, the second and third molars were missing and almost all mandible teeth were extracted before the patient was referred for treatment. Authors were concerned that implant placement into porous bone might result in lack of osseointegration and lead to complication. Thus, treatment plan consisted of fixed partial dentures preparation for the maxilla and an overdenture with copings for the mandible. The patient remained satisfied with the function and aesthetic result at the one year recall appointment.

\section{CONCLUSIONS}

Despite the exceptions, cherubism is a clinically wellcharacterized disease which confers to the patient the appearance of a baroque cherub; therefore, this derived the name of the disease. In cases of a suspicion of cherubism, radiographic examination is essential since the clinical presentation and the location and distribution of the lesions may define the diagnosis. Histopathological examination is complementary. Nowadays, genetic tests should be used for final diagnosis of cherubism.

Knowledge of the clinical and radiographic alterations observed in patients with cherubism is important since the dentist might be the first professional sought for a diagnosis of this disease.

\section{ACKNOWLEDGMENTS AND DISCLOSURE STATEMENTS}

The authors report no conflicts of interest related to this study.

\section{REFERENCES}

1. Ayoub AF, el-Mofty SS. Cherubism: report of an aggressive case and review of the literature. J Oral Maxillofac Surg. 1993 Jun;51(6):702-5. [Medline: 8492214]

2. Cabral LA, dos Santos GM. [Cherubism]. Ars Curandi Odontol. 1977 Jul;4(4):44-51. Portuguese. [Medline: 293156]

3. Kaugars GE, Niamtu J 3rd, Svirsky JA. Cherubism: diagnosis, treatment, and comparison with central giant cell granulomas and giant cell tumors. Oral Surg Oral Med Oral Pathol. 1992 Mar;73(3):369-74. [Medline: 1545971] [doi: 10.1016/0030-4220(92)90137-F]

4. Kalantar Motamedi MH. Treatment of cherubism with locally aggressive behavior presenting in adulthood: report of four cases and a proposed new grading system. J Oral Maxillofac Surg. 1998 Nov;56(11):1336-42. [Medline: 9820222] [doi: 10.1016/S0278-2391(98)90618-8]

5. Kozakiewicz M, Perczynska-Partyka W, Kobos J. Cherubism--clinical picture and treatment. Oral Dis. 2001 Mar;7(2):12330. Review. [Medline: 11355438] [doi: 10.1034/j.1601-0825.2001.0070211.x]

6. Li CY, Yu SF. A novel mutation in the SH3BP2 gene causes cherubism: case report. BMC Med Genet. 2006 Dec 5;7:84. [Medline: 17147794] [doi: 10.1186/1471-2350-7-84] [FREE Full Text]

7. Jain V, Gamanagatti SR, Gadodia A, Kataria P, Bhatti SS. Non-familial cherubism. Singapore Med J. 2007 Sep;48(9):e253-7. [Medline: 17728954] [FREE Full Text]

8. Pontes FS, Ferreira AC, Kato AM, Pontes HA, Almeida DS, Rodini CO, Pinto DS Jr. Aggressive case of cherubism: 17 year follow-up. Int J Pediatr Otorhinolaryngol. 2007 May;71(5):831-5. Epub 2007 Mar 13. Review. [Medline: 17360048] [doi: 10.1016/j.ijporl.2007.01.017]

9. Beaman FD, Bancroft LW, Peterson JJ, Kransdorf MJ, Murphey MD, Menke DM. Imaging characteristics of cherubism. AJR Am J Roentgenol. 2004 Apr;182(4):1051-4. [Medline: 15039186] [FREE Full Text]

10. Sarda D, Kothari P, Kulkarni B, Pawar P. Cherubism in siblings: A case report. J Indian Soc Pedod Prev Dent. 2007 Mar;25(1):27-9. Review. [Medline: 17456964] [doi: 10.4103/0970-4388.31986] [FREE Full Text]

11. Carvalho Silva E, Carvalho Silva GC, Vieira TC. Cherubism: clinicoradiographic features, treatment, and long-term followup of 8 cases. J Oral Maxillofac Surg. 2007 Mar;65(3):517-22. [Medline: 17307601] [doi: 10.1016/j.joms.2006.05.061] 
12. Silva GC, Gomez RS, Vieira TC, Silva EC. Cherubism: long-term follow-up of 2 patients in whom it regressed without treatment. Br J Oral Maxillofac Surg. 2007 Oct;45(7):567-70. Epub 2006 Oct 6. [Medline: 17030358] [doi: 10.1016/j.bjoms.2006.08.013]

13. Southgate J, Sarma U, Townend JV, Barron J, Flanagan AM. Study of the cell biology and biochemistry of cherubism. J Clin Pathol. 1998 Nov;51(11):831-7. [Medline: 10193324] [doi: 10.1136/jep.51.11.831] [FREE Full Text]

14. Caballero R, Vinals H. Cherubism: a study of three generations. Med Oral. 1998 May-Jul;3(3):163-171. [Medline: 11507493 ]

15. Silva EC, de Souza PE, Barreto DC, Dias RP, Gomez RS. An extreme case of cherubism. Br J Oral Maxillofac Surg. 2002 Feb;40(1):45-8. [Medline: 11883969] [doi: 10.1054/bjom.2001.0654]

16. Ramon Y, Engelberg IS. An unusually extensive case of cherubism. J Oral Maxillofac Surg. 1986 Apr;44(4):325-8. [Medline: 3457129] [doi: 10.1016/0278-2391(86)90085-6]

17. Jones WA, Gerrie J, Pritchard J. Cherubism--familial fibrous dysplasia of the jaws. J Bone Joint Surg Br. 1950 Aug;32-B(3):334-47. [Medline: 14778852] [FREE Full Text]

18. Katsikeris N, Kakarantza-Angelopoulou E, Angelopoulos AP. Peripheral giant cell granuloma. Clinicopathologic study of 224 new cases and review of 956 reported cases. Int J Oral Maxillofac Surg. 1988 Apr;17(2):94-9. Review. [Medline: 3133432] [doi: 10.1016/S0901-5027(88)80158-9]

19. Kim YG, Choi YS, Lee SC, Ryu DM. Tumor-induced osteomalacia associated with lesions in the oral and maxillofacial region: report of two cases. J Oral Maxillofac Surg. 1996 Nov;54(11):1352-7. [Medline: 8941189] [doi: $10.1016 / \mathrm{S} 0278-2391(96) 90497-8$ ]

20. Gomes MF, de Souza Setúbal Destro MF, de Freitas Banzi EC, dos Santos SH, Claro FA, de Oliveira Nogueira T. Aggressive behaviour of cherubism in a teenager: 4-years of clinical follow-up associated with radiographic and histological features. Dentomaxillofac Radiol. 2005 Sep;34(5):313-8. [Medline: 16120883] [doi: 10.1259/dmfr/32866350]

21. de Lange J, van den Akker HP, van den Berg H. Central giant cell granuloma of the jaw: a review of the literature with emphasis on therapy options. Oral Surg Oral Med Oral Pathol Oral Radiol Endod. 2007 Nov;104(5):603-15. Epub 2007 Aug 20. Review. [Medline: 17703964] [doi: 10.1016/j.tripleo.2007.04.003]

22. Curran AE, Pfeffle RC, Miller E. Autosomal dominant osteosclerosis: report of a kindred. Oral Surg Oral Med Oral Pathol Oral Radiol Endod. 1999 May;87(5):600-4. [Medline: 10348520] [doi:10.1016/S1079-2104(99)70141-1]

23. Ozkan Y, Varol A, Turker N, Aksakalli N, Basa S. Clinical and radiological evaluation of cherubism: a sporadic case report and review of the literature. Int J Pediatr Otorhinolaryngol. 2003 Sep;67(9):1005-12. Review. [Medline: 12907058] [doi: 10.1016/S0165-5876(03)00179-4]

24. Peñarrocha M, Bonet J, Mínguez JM, Bagán JV, Vera F, Mínguez I. Cherubism: a clinical, radiographic, and histopathologic comparison of 7 cases. J Oral Maxillofac Surg. 2006 Jun;64(6):924-30. [Medline: 16713807] [doi: 10.1016/j.joms.2006.02.003]

25. Von Wowern N. Cherubism: a 36-year long-term follow-up of 2 generations in different families and review of the literature. Oral Surg Oral Med Oral Pathol Oral Radiol Endod. 2000 Dec;90(6):765-72. Review. [Medline: 11113824] [doi: $10.1067 / \mathrm{moe} .2000 .108438$ ]

26. Hyckel P, Berndt A, Schleier P, Clement JH, Beensen V, Peters H, Kosmehl H. Cherubism - new hypotheses on pathogenesis and therapeutic consequences. J Craniomaxillofac Surg. 2005 Feb;33(1):61-8. Epub 2005 Jan 12. [Medline: 15694152] [doi: $10.1016 /$ j.jcms.2004.07.006]

27. Novack DV, Faccio R. Jawing about TNF: new hope for cherubism. Cell. 2007 Jan 12;128(1):15-7. [Medline: 17218248] [doi: 10.1016/j.cell.2006.12.019] [FREE Full Text]

28. Yilmaz B, Ozan O, Karaagaclioglu L, Ersoy AE. A prosthetic treatment approach for a cherubism patient: A clinical report. J Prosthet Dent. 2006 Nov;96(5):313-6. [Medline: 17098492] [doi: 10.1016/i.prosdent.2006.09.014]

29. Mortellaro C, Bello L, Lucchina AG, Pucci A. Diagnosis and treatment of familial cherubism characterized by early onset and rapid development. J Craniofac Surg. 2009 Jan;20(1):116-20. Review. [Medline: 19165006] [doi: 10.1097/SCS.0b013e318190e23c]

30. Lannon DA, Earley MJ. Cherubism and its charlatans. Br J Plast Surg. 2001 Dec;54(8):708-11. [Medline: 11728115] [doi: 10.1054/bjps.2001.3701]

31. Hatani T, Sada K. Adaptor protein 3BP2 and cherubism. Curr Med Chem. 2008;15(6):549-54. Review. [Medline: 18336269] [doi: 10.2174/092986708783769795]

32. Roginsky VV, Ivanov AL, Ovtchinnikov IA, Khonsari RH. Familial cherubism: the experience of the Moscow Central Institute for Stomatology and Maxillo-FacialSurgery. Int J Oral Maxillofac Surg. 2009 Mar;38(3):218-23. Epub 2008 Nov 26. [Medline: 19038533] [doi: 10.1016/j.ijom.2008.10.010]

33. Pulse CL, Moses MS, Greenman D, Rosenberg SN, Zegarelli DJ. Cherubism: case reports and literature review. Dent Today. 2001 Nov;20(11):100-3. Review. [Medline: 11715640$]$

34. Schultze-Mosgau S, Holbach LM, Wiltfang J. Cherubism: clinical evidence and therapy. J Craniofac Surg. 2003 Mar;14(2):201-6; discussion 207-8. [Medline: 12621291] [doi: 10.1097/00001665-200303000-00012]

35. Khader RN, Papageorge MB, Kahn M. A clinico-pathologic correlation. Cherubism. J Mass Dent Soc. 2007 Fall;56(3):40-2. [Medline: 18069593] 
36. Meng XM, Yu SF, Yu GY. Clinicopathologic study of 24 cases of cherubism. Int J Oral Maxillofac Surg. 2005 Jun;34(4):350-6. [Medline: 16053841] [doi: 10.1016/j.ijom.2004.09.006]

37. Wang CN, Song YL, Peng B, Lu DH, Fan MW, Li J, Ye XQ, Fan HL, Bian Z. The aggressive form of cherubism: report of two cases in unrelated families. Br J Oral Maxillofac Surg. 2006 Aug;44(4):322-4. Epub 2005 Nov 28. [Medline: 16310907] [doi: 10.1016/j.bjoms.2005.10.003]

38. Hart W, Schweitzer DH, Slootweg PJ, Grootenhuis LS. [Man with cherubism]. Ned Tijdschr Geneeskd. 2000 Jan 1;144(1):34-8. Review. Dutch. [Medline: 10665301]

39. Elfahsi A, Oujilal A, Lahlou M, Lazrak A, Kzadri M. [An ophthalmological complication of cherubism]. Rev Stomatol Chir Maxillofac. 2007 Feb;108(1):58-60. Epub 2007 Jan 17. French. [Medline: 17261320]

40. Henry F, Testelin S, Gauvin AC, Poirier J, Henry E. [Cherubism: the value of imaging and preoperative embolization]. J Radiol. 2003 Nov;84(11 Pt 1):1774-8. French. [Medline: 15022992]

41. Holst AI, Hirschfelder U, Holst S. Diagnostic potential of 3D-data-based reconstruction software: an analysis of the rare disease pattern of cherubism. Cleft Palate Craniofac J. 2009 Mar;46(2):215-9. Epub 2007 Nov 15. [Medline: 19254051] [doi: 10.1597/07-015.1] [FREE Full Text]

42. Mnari W, Ennouri S, Jlassi H, Mighri K, Driss N, Hamza HA. [Cherubism: a new case with review of literature]. Ann Otolaryngol Chir Cervicofac. 2005 Nov;122(5):260-4. Review. French. [Medline: 16439937] [doi: 10.1016/S0003-438X(05)82359-X]

43. de Lange J, van den Akker HP, Scholtemeijer M. Cherubism treated with calcitonin: report of a case. J Oral Maxillofac Surg. 2007 Aug;65(8):1665-7. [Medline: 17656300] [doi: 10.1016/j.joms.2006.06.266]

44. Raposo-Amaral CE, de Campos Guidi M, Warren SM, Almeida AB, Amstalden EM, Tiziane V, Raposo-Amaral CM. Two-stage surgical treatment of severe cherubism. Ann Plast Surg. 2007 Jun;58(6):645-51. [Medline: 17522488] [doi: 10.1097/01.sap.0000248141.36904.19]

\section{To cite this article:}

Lima G de M, Almeida JD, Cabral LA. Cherubism: Clinicoradiographic Features and Treatment.

J Oral Maxillofac Res 2010;1(2):e2

URL: http://www.ejomr.org/JOMR/archives/2010/2/e2/e2ht.pdf

doi: $10.5037 /$ jomr.2010.1202

Copyright (C) Lima G de M, Almeida JD, Cabral LA. Accepted for publication in the JOURNAL OF ORAL \& MAXILLOFACIAL RESEARCH (http://www.ejomr.org), 15 March 2010.

This is an open-access article, first published in the JOURNAL OF ORAL \& MAXILLOFACIAL RESEARCH, distributed under the terms of the Creative Commons Attribution-Noncommercial-No Derivative Works 3.0 Unported License, which permits unrestricted non-commercial use, distribution, and reproduction in any medium, provided the original work and is properly cited. The copyright, license information and link to the original publication on (http://www.ejomr.org) must be included. 